\title{
Share Purchase Plans in Australia: Issuer characteristics and valuation implications ${ }^{\#}$
}

\author{
Philip Brown $^{*}$, Andrew Ferguson ${ }^{* *}$ and Kate Stone ${ }^{* * *}$
}

\begin{abstract}
Share purchase plans (SPPs) are offered exclusively to a company's registered shareholders, who may purchase up to $\$ 5,000$ worth of shares in a 12 month period at a discount to the market price and without any brokerage charge. They have become one of the most frequently used mechanisms for raising publicly-traded equity capital in Australia, yet little is known about them from a financial markets perspective. We address this deficiency by documenting the characteristics of Australian firms that have adopted SPPs and assessing their short term and long term valuation implications. We find that SPPs are more likely to be issued by firms with lower levels of liquidity and relatively large numbers of shareholders. They have a negative announcement effect, which is associated with the size of the issue, the prior share price runup, the issue price discount, the firm's industry, and whether there is enough time for non-shareholders to buy shares in order to participate. Long run underperformance is also found over extended periods, consistent with much of the seasoned equity offering (SEO) literature. The SPP-issuer did not perform as badly if it was in the mining industry, if it was audited by a 'Big- $N$ ' firm, or if the issue was underwritten. Conversely, the greater the issue discount the worse the issuer's long run performance.
\end{abstract}

Keywords: Share purchase plans, seasoned equity offerings, underperformance

\footnotetext{
\# This research, which is an outgrowth of Kate Stone's UNSW BCom honours thesis, was partly funded by ARC grant DP0556440.

* Professor, Australian School of Business UNSW and UWA Business School.

***Associate Professor, Australian School of Business UNSW and corresponding author (email to: a.ferguson@unsw.edu.au).

${ }^{* * *}$ Analyst, Credit Suisse (Australia) Ltd. The views expressed in this paper are those of the authors and do not necessarily reflect the views of Credit Suisse (Australia) Ltd.
} 


\section{Share Purchase Plans in Australia: Issuer characteristics and valuation implications}

\section{Introduction}

We investigate three aspects of share purchase plans [hereafter SPPs]: (1) the characteristics of firms that issue shares via SPPs; (2) how share prices behave around the time of an SPP announcement; and (3) the long term investment performance of firms that implement an SPP. Apart from our own work, ${ }^{1}$ no research has been published on SPPs so far.

SPPs are a form of seasoned equity offering (SEO). The first Australian issue via an SPP was undertaken by CSR in 1991 when it offered shareholders the opportunity to subscribe for new shares worth $\$ 2,400$ (The Intelligent Investor 2005). Following regulatory changes in September 2002 that allowed for subscriptions up to a maximum of $\$ 5,000$ per shareholder (the prior cap was $\$ 3,000$ ), the popularity of SPPs has increased substantially. $^{2}$

The focus of the Australian literature on equity raisings has been largely on initial public offerings (IPOs). Two studies (Dehnert 1992 and 1993) in the last 15 years have addressed the share price reaction to various SEO announcements in Australia, while three (Allen and Soucik 1999a, Allen and Soucik 1999b and Brown, Gallery and Goei 2006) have addressed aspects of long run performance following an SEO. We extend this literature by examining evidence of both short and long run performance associated with an SPP issue. This evidence is interesting given SPPs do not require the issue of a prospectus, indicating the issue can occur within a more asymmetric information environment than rights issues, which during the sample period did require a prospectus.

Using a total sample of 591 SPPs issued in Australia from 1991 to 2005, we find SPP-issuers are characterised by their lower levels of liquidity and cash holdings and by their more disperse share registers, when compared with other firms in the same industry

\footnotetext{
${ }^{1}$ See Brown, Ferguson and Stone (2006) for a summary.

2 The increasing popularity of SPPs is shown by the $220 \%$ increase in the number of plans from 2001 to 2002 (39 SPPs were announced in 2001 compared to 125 plans in 2002). The total issue proceeds from SPPs in 2003 were $\$ 1,335$ million compared to $\$ 25,663$ million from all SEOs (Australian Stock Exchange 2004).
} 
and of comparable size. There is a negative share price reaction to the announcement of an SPP, measured relative to the market return in the announcement period. The size of the reaction is related to the size of the issue, the prior share price runup, the issue price discount, the firm's industry, and whether there is enough time for non-shareholders to buy shares in order to participate. We also document significant underperformance for some years after the event. The SPP-issuer did not perform as badly if it was in the mining industry, if it was audited by a 'Big- $N$ ' firm, or if the issue was underwritten. Conversely, the greater the issue discount the worse the issuer's long run performance.

The remainder of our paper is structured as follows. Section 2 reviews prior literature and sets out our predictions for each of the three components of the study: SPP issuer characteristics, announcement effects, and the long run investment performance of SPP issuers. Section 3 lays out the research method and describes the data. Section 4 contains the results and Section 5 concludes the paper.

\section{Prior Literature and Predictions}

\subsection{SPP issuer characteristics}

Lee and Kocher 2001 compare the characteristics of firms making private placements with those issuing shares by public offering. They analyse six determinants, including firm size, dividends, growth opportunities, free cash flow, overvaluation and ownership fraction. Burton and Power 2003 examine the decision between a rights issue and a private placement. They examine seven attributes where theory suggests differences might exist between the two classes of equity issuer: firm size, growth opportunities, liquidity, profitability, dividend behaviour, the offer method used for the most recent previous equity issue, and shareholder structure.

Based on the equity issuance literature, we posit a model to predict the issue of SPPs. A comparison of the characteristics of SPP-issuing firms and a matched sample of non-SPP-issuing firms is conducted. Eight firm characteristics are identified from the prior literature and analysis of SPPs: growth and investment opportunities, liquidity, profitability, cash holdings, leverage, dividend behaviour, shareholder structure, and overseas exchange listing. We control for a ninth factor, firm size, in much of the analysis. 
Intuitively, firms with greater growth and investment opportunities are more likely to raise additional equity capital. However, studies show public offering and rights issuers typically have lower growth and fewer investment opportunities (Lee and Kocher 2001 and Burton and Power 2003). Consequently, we make no directional prediction for this variable. For liquidity, the pecking order theory (Donaldson 1961, Myers and Majluf 1984) predicts firms issuing SPPs are less liquid.

Pecking order theory and empirical evidence differentiating between debt and equity issues leads us to predict equity issuing firms are less profitable. However, the free cash flow argument (Jensen 1986), also supported by evidence, indicates public offerors and rights issuers are more profitable than placement firms (Hertzel and Smith 1993). Thus we do not predict the direction of any relationship for profitability. Two conflicting predictions also apply to cash holdings. Specifically, the pecking order theory predicts a negative relationship, while a positive relationship is predicted by the free cash flow argument. Consequently no direction is predicted for this relationship either. Similarly, no directional prediction is made for leverage. In terms of dividend behaviour, both the pecking order and free cash flow theories predict a negative relationship between issuing SPPs and the payment of dividends (Kocher and Lee 2001, Burton and Power 2003).

Eckbo and Masulis 1992 show the importance of current shareholder demand for a new equity offering. Managers expecting low (high) shareholder participation select firm commitment public offers (rights issues). An issue feature of SPPs has restricted firms to issuing shares up to a current maximum of $\$ 5,000$ to each shareholder. We suspect this feature is the result of regulators' conservatism and is unrelated to any concerns about shareholder concentration or managerial ownership. Given the upper limit per shareholder, the aggregate amount a firm can raise this way depends on the number of shareholders. We thus predict a firm with a larger number of shareholders is more likely to issue an SPP, all else equal.

Lastly, an SPP is generally restricted to shareholders who are residents of Australia or New Zealand. This is for practical reasons as well as the fact that offers of this nature are illegal in some foreign jurisdictions. For a firm to maximise the issue proceeds, its shareholders must be eligible to participate. A firm listed only on the 
Australian or New Zealand stock exchanges probably has a greater proportion of Australian and New Zealand shareholders and thus will be more likely to issue an SPP.

To summarise, we predict SPPs are more likely to be adopted by firms that are less liquid, do not pay dividends, have a more disperse share register, and are traded only in Australia and New Zealand. Other factors likely to matter are the firm's growth opportunities, profitability, cash holdings and leverage, but there are conflicting views with respect to the direction of any effect they may have.

\subsection{SPP announcement effects}

SPPs provide a unique opportunity to measure the relative influence of factors related to the overall announcement effect because the SPP detail announcement includes specific information regarding the plan, such as the record date for eligible shareholders, the closing date for applications and instructions on how to participate.

The literature contains mixed evidence regarding the announcement effect of different types of equity issue. In the US, the stock price declines by $3 \%$ on average for underwritten public offers and by a smaller amount for rights issues. In contrast, issuers in the UK and in many other European countries typically exhibit a large negative share price reaction to rights issue announcements and an insignificant or even positive reaction to public issues. Private placements seem to impact positively.

SPPs are a unique offering displaying features of different equity issues. For example, SPPs constitute a public issue but are often issued jointly with a private placement. However, SPPs are restricted to existing shareholders and are arguably similar in nature to a rights issue. Given the mixed results in the prior literature no direction is predicted for the pricing implications of the SPP detail announcement. However, prior SEO literature such as Masulis and Korwar 1986, Eckbo and Masulis 1992, Slovin, Sushka and Lai 2000 and Gajweski and Ginglinger 2002 indicate the following factors might cause different share price reactions to SPP announcements: the size of the firm, the relative size of the offer, the offer discount, the issuer's industry, any prior share price runup, the intended use of the proceeds, whether the issue is underwritten, the extent of directors' participation, and whether there is an accompanying private placement. 
The information asymmetry hypothesis and evidence suggest the magnitude of the share price reaction is negatively related to the anticipated size of the offering when it is announced. The anticipated issue size is not necessarily the actual amount raised, since the number of shares issued under the SPP is not known until allotment. ${ }^{3}$ Unfortunately, not all firms disclose the anticipated amount. Disclosing firms reveal either the anticipated amount or the maximum amount the firm can raise subject to ASX Listing Rules and ASIC restrictions. Therefore our measure of relative offer size (anticipated) is not ideal.

Eckbo and Masulis 1992, Gajewski and Ginglinger 2002 and Slovin, Sushka and Lai 2000 report inconsistent evidence regarding the relationship between the issue price discount and the market reaction to the offering, so no directional prediction is made. Many factors could determine the discount for an SPP. One is that the discount must be large enough for the board to be confident that, when the plan closes, the issue price is still below the market price, otherwise shareholders will not subscribe. Further, the discount is limited by the ASX Listing Rules, which stipulate the issue price must be at least $80 \%$ of the average market price for securities in that class. The average is calculated over the last 5 days on which sales were recorded, either before the day the SPP details are announced or before the day the issue is made.

Empirical findings and the information asymmetry hypothesis suggest the share price reaction to the SPP detail announcement will be less favourable for industrial firms than for public utilities. The basic argument should be particularly applicable to the Australian share market, which includes a sizeable number of mining firms. Ferguson and Crockett 2003 argue mining companies are subject to greater information asymmetry due to the specialized and highly technical nature of geological information. Thus we predict the share price reaction to the SPP detail announcement will be less favourable for mining firms. ${ }^{4}$

Masulis and Korwar's 1986 cross-sectional analysis of returns in the announcement period shows a negative relationship to prior share returns (measured over the preceding three months). This result is consistent with Helou and Park 2001, who

\footnotetext{
${ }^{3}$ Underwritten issues are an exception.

${ }^{4}$ We classify firms with GICS sector codes of 15 (Materials) or 10 (Energy) as mining firms.
} 
measure share price runup over the preceding two months, and Gajewski and Ginglinger 2002, who employ a 200 day measurement window. The evidence suggests the negative relationship arises from the decision of managers to postpone equity issues when the firm is undervalued. They prefer to wait until they believe the stock is no longer undervalued, which is consistent with the information asymmetry hypothesis: that a firm will issue equity and create financial slack when conditions favour an equity issue. That argument is supported by Gajewski and Ginglinger 2002, who report no significant difference between underwritten public offerings and standby rights issues in terms of the issuing firm's prior performance. Their results are in contrast to Asquith and Mullins 1986, who show announcement period returns are positively related to the share price runup over the preceding 12 months. Given the more recent evidence, we predict a higher share price runup will be associated with a more negative announcement effect.

The pecking order theory predicts firms will use equity financing as a last resort, and is consistent with the argument that there is an unfavourable share price reaction when an equity issue is used to refinance debt. Thus we predict a more unfavourable share price reaction for SPPs that announce the proceeds are to be used this way.

The information asymmetry argument suggests an underwriter plays a signalling role by credibly monitoring and certifying the issuing firm. Since SPPs do not need to be underwritten (ASX Listing Rule 7.1), the decision to spend additional monies on underwriting is a positive signal. Therefore, we predict the announcement effect will be more favourable when the SPP is underwritten.

The 'underwriter certification' argument suggests a less unfavourable share price reaction when the price of an underwritten issue is known beforehand. Under a firm commitment offering in the US, the price is not set until after the announcement, giving rise to a potentially negative announcement effect. SPPs are an interesting setting because they do not have to be underwritten and there is no restriction regarding when the price of the plan must be announced. We predict a less favourable reaction to an SPP detail announcement when the price of the plan is not stated until later.

SPPs offer existing shareholders the opportunity to pay a fixed maximum dollar amount to subscribe for additional shares. The offer is not on a pro rata basis but rather it is an equal entitlement independent of the number of shares already held. Directors can 
participate in SPPs which, according to Leland and Pyle's 1977 signalling hypothesis, suggests a favourable share price reaction when they do. Some firms indicate in the SPP detail announcement that the directors will take up their full entitlement. Therefore we predict a more favourable announcement effect when directors state they will participate in the plan.

Many SPPs are announced concurrently with a private placement. Wruck 1989 and Hertzel and Smith 1993 report the market reacts positively to private placements. Based on their evidence, we similarly predict a favourable announcement effect where the SPP is accompanied by a private placement during the SPP offer period.

Lastly, the record date can be important because it is the date when the issuer determines who may participate in the SPP. For some plans the record date occurs before the SPP detail announcement so that non-shareholders are unable to purchase shares and become eligible to participate. For other plans the record date is after the SPP detail announcement and the share price potentially could be affected by the actions of nonshareholder investors wishing to participate. ${ }^{5}$ We predict the announcement effect will be more favourable for plans that have a record date after the announcement date, due to temporary order imbalance reflecting the increased demand for the stock. However, it may not be a significant factor because a would-be investor needs to hold only one share to qualify. There is likely to be an offsetting, negative effect, because the additional shares are offered at a discount. This effect, too, on average will be small (of the order of $0.5 \%$ ) because the average discount is about $10 \%$, the issue size averages about $15 \%$ of previous capital and any dilution effect on share prices is likely to occur closer to the record date, which is after the announcement period for a substantial fraction of SPPs (refer Table 2, discussed below).

In summary, we predict a less favourable market reaction to an SPP's announcement by a mining firm, where the offer is larger, the prior runup is greater, the proceeds are used to settle debts, the issue is not underwritten, directors do not commit to participating, there is no accompanying private placement, the issue price is unknown and the record date is either before or within the event period. We make no specific prediction

\footnotetext{
${ }^{5}$ In $43 \%$ of cases the record date is more than five days after the announcement (see Table 2).
} 
about the direction of any association with firm size or the size of the offer discount, but acknowledge that it could be statistically different from zero.

\subsection{The long run investment performance of SPP issuers}

The literature has identified many factors affecting the post-offer returns of IPOs and SEOs (Brown, Gallery and Goei 2006). Auditor reputation and audit opinion type, presence of an underwriter and director participation are among them. Weber and Willenborg 2003 examine the informativeness of the audit report contained in a firm's IPO prospectus. They focus on microcap IPOs, a segment of the market with a relatively poor record for long run performance. It is argued the presence of outside experts can convey valuable information to investors. Often the audit firm is the sole (if any) expert involved. The findings suggest the pre-IPO opinions of the large ('Big- $N$ ') audit firms are better predictors of a post-IPO stock performance. Large audit firms are also more likely to issue a going concern opinion on their financially distressed clients. We thus predict the appointment of a large audit firm will mitigate future long run underperformance. We also consider the audit opinion, and predict poorer long run performance by companies with qualified audit reports.

In a similar manner, underwriters can protect their reputation by marketing firms with better prospects. Chemmanur and Fulghieri 1994 argue investors use the quality of the underwriter to assess the credibility of the equity issuer. ${ }^{6}$ Carter, Dark and Singh 1998 find the underperformance of IPO stocks relative to the market over a three year holding period is less severe for IPOs handled by more prestigious underwriters. Their finding is consistent with Michaely and Shaw 1994, who use the investment bank's capital as a proxy for prestige. In a similar vein, Brav and Gompers 1996 show venture-capitalbacked IPOs outperform other offerings over the first five years. Thus we predict a positive relationship between the presence of an underwriter and the subsequent long run stock performance of the issuer.

We referred in Section 2.2 to Leland and Pyle's 1977 signalling model, which predicts a change in management holding triggers a change in firm value in the same

\footnotetext{
${ }^{6}$ Quality of the underwriter is determined by the quality of the firms in which they have previously sold equity.
} 
direction. Likewise, Datar, Feltham and Hughes 1991 suggest the retention of ownership by an entrepreneur is a credible signal regarding their private information about the firm's future prospects. Balatbat, Taylor and Walter 2004 test the cross-sectional relationship between long run operating performance and percentage retention of directors' share ownership for 313 Australian IPOs between 1976 and 1993. Retained ownership was significantly related to performance in years 4 and 5. The signalling argument suggests director participation in an equity offering is a credible signal regarding the firm's future performance. Therefore, we predict a positive relationship between director participation in the SPP and subsequent long run stock performance.

\section{Data and Method}

\subsection{SPP issuer characteristics}

We match each SPP issuer with another firm in the same industry (using either the 10 GICS industry sectors or the ASX 2-digit industry number, as available at the time of the issue) and of comparable size, based on market capitalisation as at the last balance date before the SPP detail announcement. Bradley, Jarrell and Kim 1984 illustrate industry is an important matching variable by reporting industrial classifications determine approximately $54 \%$ of the cross-sectional variance in leverage ratios. Three other proxies for firm size are total assets (Taub 1975 and Burton and Power 2003), capital employed (Marsh 1982) and sales (Chiarella, Pham, Sim and Tan 1991 and Titman and Wessels 1988). We do not use the last two measures because a substantial proportion of our sample comprises mining and oil exploration companies, for which they are less reliable indicators of scale. We exclude other SPP-issuing firms as a potential match.

Two methods are used to examine the difference between SPP-issuing firms and their matched counterparts. First, we assess differences in means via a $t$-test and also conduct a non-parametric Wilcoxon signed rank test on each explanatory variable. Second, a multivariate model is used to predict whether a firm is likely to issue an SPP based on a number of firm characteristics. We fit the model via logistic regression, similar to Cragg and Baxter 1970, Taub 1975, Marsh 1982 and Burton and Power 2003. The dichotomous dependent variable $=1$ for the SPP-issuing firm and $=0$ for its match. 
The explanatory variables include growth and investment opportunities, liquidity, profitability, cash holdings, leverage, dividend behaviour, shareholder structure and overseas exchange listing (other than New Zealand). These variables are measured as at the last available balance date prior to either the SPP detail announcement or, where that date is unavailable, the date of the first announcement of the plan. To cater for extreme values, all continuous explanatory variables are winsorised at the $2 \%$ level. $^{7}$

The total sample includes all SPPs announced between 1991, when the first SPP was implemented, and 30 June 2005. The sample was identified by a triangulation of several data sources utilising key word searches. The key words used were "SPP", "purchase plan" and "purchase scheme". Further analysis of the search results was required to correctly identify SPPs, for instance by eliminating employee share purchase plans. The primary data sources were Factiva (specifically searching ASX Company Announcements from August 1992), Aspect/Huntley DatAnalysis, and Signal G Announcements. $^{8}$

Daily share price and return data are sourced from the Securities Industry Research Centre of Asia-Pacific (SIRCA) core research database. Market capitalisation and monthly return data are sourced from the AGSM's Centre for Research in Finance SPPR (Share Price/Price Relative) database. Accounting input variables are sourced from the Aspect/Huntley FinAnalysis database. Data relating to the provisions of each SPP were hand collected from ASX announcements.

Table 1 provides a yearly breakdown by industry of the number of SPPs and the number of issuers from 1991 to mid-2005. ${ }^{9}$ We note the following. First, the overall number of plan announcements increases over the period, particularly in 2002. This

\footnotetext{
${ }^{7}$ Additional analysis, not reported in detail, confirms the results are insensitive to winsorising at the $1 \%$ and $3 \%$ levels.

${ }^{8}$ The triangulation yielded a sample of 604 individual SPPs. Seven plans were subsequently terminated (abandoned) and were excluded from the sample. A further six plans were excluded because we could not determine whether the SPP was completed, despite a thorough search of the data sources. After exclusions the total sample is 591 SPPs implemented by 393 firms between 1991 and 2005. Six firms announced an SPP in the early 1990s with substantially different features from the rest of the SPPs. They were issued monthly or quarterly and with a different offer price each period. They enabled shareholders to top-up their existing shareholdings and allowed up to $\$ 500$ of shares to be purchased. Since there was no SPP detail announcement and only a change in capital announcement, these six plans were not included in the initial sample of 604.

${ }^{9}$ Based on the calendar year in which the SPP detail announcement (or failing that, the first announcement of the SPP) occurred.
} 
corresponds to the change in the ASIC regulations in September 2002 that allowed registered shareholders to purchase up to $\$ 5,000$ worth of shares, in contrast to the earlier $\$ 3,000$ maximum (ASIC 2002). ${ }^{10}$ Second, the sample includes substantial numbers of materials firms (32\%), financial firms (17\%), health care firms (12\%) and energy firms $(8 \%)$. The large number of materials firms is consistent with Brown, Gallery and Goei's 2006 SEO announcements from 1993 to 2001 and the composition of ASX listings. The Prosser Report 2003 suggests materials firms may be attracted to utilising SPPs. The report raises concerns that juniors in both the mineral and petroleum sectors have experienced difficulty raising capital in Australia. ${ }^{11}$ As a result they have tended to raise additional funds from the speculative end of the equities market. ASIC argues SPPs "assist shareholders and industry to participate in more cost-effective fundraising without unduly compromising investor protection."12 Because of the relatively large number of mining firms issuing SPPs (237 plans or $40 \%$ of our sample) we conduct additional analysis to ensure our results are robust to industry effects. Third, a number of firms issued more than one SPP over the sample period. Three hundred and ninety-three firms issued at least one and 100 firms issued more than one. The largest number of issues by any one firm was 12, by Lend Lease Corporation, which was followed by Argo Investments Limited with 11 (both are financial firms).

[Table 1]

\footnotetext{
${ }^{10}$ The increase in SPPs is consistent with anecdotal evidence that "SPPs accompanying institutional placements have become so popular in the last two years that they are overtaking rights issues as a way of capital raising" (McCallum 2002). One reason for the increased prevalence of SPPs is "in the right circumstances, they can be good for both the company and its small shareholders" (The Intelligent Investor 2005). Further, companies are attracted to SPPs "because they do not involve the costs or time delays involved in issuing a prospectus for a rights issue, they do not need an underwriter and there is no period of uncertainty for the stock while the rights are traded" (McCallum 2002). This is consistent with Brown, Gallery and Goei's 2006 finding that private placements have become an attractive method of fund raising because they allow firms to obtain capital relatively cheaply and quickly. Brown, Gallery and Goei 2006 highlight the increase in the frequency of placements follows the Australian Corporations Law Amendments of 1994. In 1993, $47 \%$ of their sample were placements in comparison to more than $80 \%$ in 1994. SPPs seem to have been unaffected by this legislative change, as illustrated by the small change in the number of SPPs from 1993 to 1994.

11 'Juniors' are defined in the Prosser Report as small exploration companies and implicitly non-producers with a market capitalisation below $\$ 200$ million.

${ }^{12}$ Media release IR 02/17 ASIC amends policy on share purchase plans, Wednesday 18 September 2002.
} 
Descriptive statistics for the full sample of SPPs are presented in Panel A of Table 2. The mean discount for the sample is $11.12 \%$. The average SPP raised $\$ 10.4$ million, or about $7.2 \%$ of the pre-existing market capitalization. ${ }^{13}$ The average time taken to effect the issue was 51 days, while the average uptake rate was $66 \%$. Panel B of Table 2 provides descriptive statistics for the share price reaction and factors possibly affecting the reaction to the SPP detail announcement. The mean (median) anticipated relative offering size was $14.8 \%$ (12.9\%). Because firms often indicated the maximum amount allowed subject to ASX Listing Rules and ASIC restrictions rather than the amount expected to be raised, alternative measures of size are employed in the analysis, including the $\log$ of $15 \%$ of the firm's market capitalisation on the announcement date (relative offering size (restricted)) and the natural logarithm of the dollar value of total assets. Table 2 indicates a mean (median) of 15.7 (15.3) and 17.3 (16.7) respectively for these measures. It also shows an average $6.1 \%$ runup over the last 60 trading days (about three calendar months) before the announcement (median 3.3\%) but there is a wide range (minimum $-59.8 \%$, maximum $106.5 \%$ ). One in 10 plan announcements stated funds would be used to settle debts or otherwise strengthen the balance sheet, one in eight stated that directors would participate, $12 \%$ that the issue was underwritten, $71 \%$ gave the issue price, $39 \%$ stated that there was an accompanying private placement, while in $43 \%$ of cases the record date was more than five days after the announcement date.

\section{[Table 2]}

Table 3 contains summary statistics by company. The mean (median) age of SPPissuing firms is 14.52 (10.05) years from their initial listing date, which is older than the 9.94 (8.00) years reported in Brown, Gallery and Goei 2006 for their sample of private placements and rights issues. The mean (median) log size of SPP-issuing firms is 22.36 (21.86) and 17.66 (16.84) for measures of market capitalisation and total assets respectively. Comparison to Brown, Gallery and Goei 2006 indicates SPP-issuing firms

\footnotetext{
${ }^{13}$ The maximum issue size of $63 \%$ of previous market capitalisation (greater than the theoretical maximum of $15 \%$ ) relates to a company that undertook a placement in conjunction with its SPP but did not provide a breakdown of proceeds under the two methods in a subsequent Appendix 3B. A small number of plans shared this characteristic. (Recall that extreme values are winsorised.)
} 
are on average larger than firms making private placements or rights issues. The two measures for growth and investment opportunities (book-to-market value of equity and capital expenditure scaled by total assets) indicate SPP-issuing firms have relatively high growth and greater investment opportunities: the sample means (medians) are $0.13(0.01)$ and 0.09 (0.04) respectively. Further comparison to Brown, Gallery and Goei 2006 confirms this result, with an average book-to-market value of equity ratio of 0.78 for their total sample. This is consistent with the discussion above regarding the use of proceeds. Specifically, mining companies often indicated the proceeds would be used to fund a feasibility study, or to develop a specific project, or for exploration. Many of the relevant assets would be 'off-balance sheet'.

\section{[Table 3]}

The current ratio, a measure of liquidity, has a mean (median) of 4.83 (1.77). SPP-issuing firms typically have positive free cash flow (mean and median are 0.05 and 0.09 respectively) but are not profitable (mean EBITDA -0.15, median -0.04). Measures of cash holdings suggest firms issuing SPPs generally have insufficient cash holdings or are using more cash than they received or held last year. The two leverage ratios show great deviation, with near-extreme minimum and maximum values. However, the median indicates the sample characteristically is not highly levered. This is consistent with the pecking order theory; that is, if not enough cost-effective debt can be borrowed then firms will resort to external equity. It is not surprising, given SPP-issuers generally are unprofitable and have limited cash holdings, that only $36 \%$ pay dividends. The measure for shareholder structure has a mean (median) of 0.48 (0.49), which implies the tendency is for the top 20 and other shareholders in SPPs firms to hold about half the issued capital. The mean overseas exchange dummy (0.82) indicates most SPP-issuing firms are listed only on the Australian or New Zealand stock exchanges.

Data attrition is documented in Table 4. One hundred and eighty-three cases were lost through lack of data when analysing the financing decision and 330 when analysing announcement effects.

[Table 4] 


\subsection{SPP announcement effects}

Many methods have been employed to measure the share price reaction to the announcement of a security issue. Masulis and Korwar 1986 use the "comparative period return" approach. The announcement period is the announcement date and the following trading day. The comparative period is the average daily return for the 60 trading days immediately following the announcement period. This comparison period is presumed to reflect the stock's 'normal' rate of return.

An alternative method (Mikkelson and Partch 1986, Wruck 1989, Burton, Lonie and Power 1999, Slovin, Sushka and Lai 2000, Helou and Park 2001 and Hertzel, Lemmon, Linck and Rees 2002) is to measure the average daily prediction error from some variation of the market model, sometimes including pre-event returns. However, the market model is unattractive when used in this way because (1) any pre-event runup, captured in the constant term, will impart a downward bias in the post-event abnormal return, and (2) the narrow event window means that any influence of risk on expected return should be immaterial. We measure abnormal return by the difference between the stock's $(\log )$ return and the market $(\log )$ return over the event window. The ASX All Ordinaries Accumulation Index is used to calculate the daily market return.

The reconciliation of the sample used to capture the announcement effect is contained in Panel B of Table 4. For 48 plans, no SPP detail announcement was provided to the ASX. Of the 48, 37 were before 2002. One in three of the earlier plans did not provide details but since then the ratio has fallen to about one in 50. A further six plans had insufficient share price data, preventing the measurement of their returns. In addition, 276 plans did not have data relating to one or more of the explanatory variables, in particular, the relative offering size (both anticipated and restricted), share price runup or discount (both calculated and stated).

\subsection{The long run investment performance of SPP issuers}

Long horizon event studies employ numerous methods to measure the long run performance of firms. Concerns arise regarding the most appropriate benchmark, holding period and test statistic to employ. There is also the question, how should returns 
measured over shorter periods be aggregated over longer periods? Gray and Whittaker 2003 illustrate the importance of methodological choice for Australian studies, with results showing various choices can induce spurious negative abnormal returns of $50 \%$ or more.

Many measures are sensitive to the length of the time horizon examined. Most long horizon studies focus on one, three and five year holding periods (e.g., Ritter 1991 and Spiess and Affleck-Graves 1995). Spiess and Affleck-Graves 1995 for instance found a positive performance in the first month following an SEO and subsequent negative performance for up to five years. Due to the short history of SPPs and the dramatic increase in their usage since 2002, we report long run performance over one, two and three years after the announcement.

Common measures of long run abnormal return include raw return, cumulative abnormal return (CAR), buy-and-hold abnormal return (BHAR) and the calendar-time portfolio approach. Barber and Lyon 1997 find inferences are less problematic when CARs are employed. However, this measure is subject to criticism. First, CARs bear little resemblance to the returns that actually accrue to a long horizon investor. Second, cumulating short-term returns over multiple periods can induce an upward bias in measured performance as a result of market microstructure problems (Conrad and Kaul 1993). Third, there is an implicit assumption that the portfolio is re-balanced to equal weights each period.

A further choice is the decision about how to measure 'return'. Gray and Whittaker 2003 illustrate the effects of employing continuously compounded (log) returns in long horizon event studies. Specifically, the magnitude of the (negative) abnormal performance measured under continuous compounding increases with the horizon period. Recognising this weakness, we focus on buy-and-hold returns.

BHARs are calculated by taking the return on the stock over the entire holding period and subtracting the return on a benchmark. The benchmark return in principle is used to estimate the unobservable status quo return on the event firm if the event had not happened. Most long horizon event studies use either a matched single firm or a matched reference portfolio as the benchmark. Ang and Zhang 2004 show the reference portfolio approach has more power, but the single firm approach is well specified and has 
comparable power for longer holding periods. We employ both benchmarks when calculating 'abnormal' BHARs: a comprehensive market index and a single, matched non-SPP issuing firm of comparable size and in the same industry. The market index is the AGSM/CRIF equally-weighted monthly returns index. The industry match is according to the GICS code, or if that is not available, then the ASX industry code; and size is according to the firm's market capitalisation at the end of the month prior to the SPP detail announcement.

An alternative measure is the calendar-time portfolio abnormal return (CTAR), which is advocated by Fama 1998. The CTAR is directed at determining whether the mean abnormal return is non-zero and is implemented as follows. For each period (say, a calendar month) a portfolio is formed from firms that have experienced the same type of event within some pre-determined number of months prior to the given month. The monthly return of the event portfolio is computed as the equally weighted average of the monthly returns of all firms in the portfolio. The time series of the monthly portfolio return in excess of the risk-free rate is tested against an asset pricing model. Commonly, the three-factor model of Fama and French 1993 is used or an extension of it, such as the addition of a momentum factor. Ang and Zhang 2004 compare the power of BHARs and the calendar-time approach and find they are similar for a one year horizon. For three and five year horizons, BHARs have greater power at nearly all levels. For this reason, we concentrate on BHARs and confine the CTAR method to a robustness test.

Many studies have addressed the appropriateness of various statistical tests used to demonstrate significant abnormal long run performance (Barber and Lyon 1997, Eckbo, Masulis and Norli 2000 and Ang and Zhang 2004). Tests analysed include the $t$ test, signed rank test, Johnson's skewness-adjusted $t$-test and bootstrapped Johnson's skewness-adjusted $t$-test. The $t$-test and signed rank test statistics are applied in our study, given both are reasonably well specified, especially when using a single matched firm benchmark, and they have the greatest power across four common alternatives (Ang and Zhang 2004).

\section{Results}

\subsection{Characteristics that differentiate SPP firms}


Table 5 contains summary statistics for SPP issuers and their matched pairs. The two groups are not significantly different in terms of size (differences in both market capitalisation and total assets are insignificant at the $10 \%$ level), confirming the integrity of the size matching procedure. The main differences arise in firms' liquidity, profitability, cash holdings, dividend behaviour and shareholder structure. Liquidity is significantly different (based on a $t$-test), indicating firms resort to issuing equity when they have insufficient liquid reserves. All measures of profitability and cash holdings are significantly different at the $5 \%$ level or better (on both the means and ranks tests) with SPP firms being on average less profitable and having lower cash holdings. Further, consistent with the pecking order theory, significantly fewer SPP-issuing firms pay dividends. However, they may be less able to pay dividends because they are unprofitable or may have little free cash flow problem to mitigate. SPP firms have a significantly larger proportion of non-top 20 shareholders, which is a proxy for the number of shareholders from whom funds may be raised. Arguably firms with a larger number of registered shareholders have the potential to raise a greater amount under an SPP.

\section{[Table 5]}

Table 6 presents the multivariate logit results, where the dependent variable reflects whether the firm issued an SPP. The base model proxies include CapEx/TA for growth and investment opportunities, EBITDA/TA for profitability, net cash for cash holdings and TD/(TD+MVE) for leverage. ${ }^{14}$ The pseudo $R^{2}$ for the base model is $9.5 \%$ and the Chi-square statistic is significant at the $1 \%$ level. While the explanatory power is modest, it exceeds the $4.74 \%$ and below reported by Burton and Power 2003 when predicting whether an equity issue consisted of a private placement or a rights issue. Three firm characteristics are significant at the $10 \%$ level or better: liquidity, cash holdings and shareholder structure. The negative coefficient for liquidity indicates SPP issuers do not have sufficient liquid reserves and thus resort to an equity raising. Cash holdings has a negative coefficient, which supports the pecking order theory rather than

\footnotetext{
${ }^{14}$ See Tables 2 and 3 for variable definitions. Sensitivity tests include the use of alternative proxies for growth (BVE/MVE), profitability (FCF/TA) and leverage (TD/TA). The alternatives yield similar classificatory power (about $64 \%)$ and similar pseudo $R^{2}(8.3 \%$, significant at $p<0.01)$.
} 
the free cash flow argument. Finally, the percentage held by non-top 20 shareholders is significantly positive. This is consistent with SPP firms having a larger number of eligible shareholders and thereby the potential to raise more funds by an SPP. The classificatory accuracy of the base model is $65 \%$.

[Table 6]

Sensitivity analysis of the base model is also presented in Table 6. The second model in Table 6 excludes all financial firms, to be consistent with most empirical research addressing capital structure (Antoniou, Guney and Paudyal 2002). This model has a pseudo $R^{2}$ of $10.15 \%$, consistent with the base model. The only differences are that the predicted direction is found for both dividend behaviour and overseas exchange, although again neither coefficient is significant. Mining firms are used exclusively in the third model, the aim being to identify any greater predictive ability in an industry having higher information asymmetry. The pseudo $R^{2}$ is $12.08 \%$ but the classificatory accuracy increases marginally. Finally, two models are fitted to SPPs with and without an associated placement. Consistent with the univariate analysis, the results show minimal difference between the two sub-samples. The main difference arises from liquidity, which is not statistically significant for cases where there was no private placement.

\subsection{SPP announcement effects}

Table 7 shows the average share price reaction to the SPP detail announcement, over the day -1 to 0 announcement window, is $-0.4 \%$, which according to a standard $t$-test is insignificant at the $10 \%$ level. However, returns are characterized by skewness and kurtosis, and the ranks test is significant at the 5\% level. The return for the four days before the announcement is on average $+0.7 \%$ (significant at the $5 \%$ level for a $t$-test but not significant for a Wilcoxon test); and it averages $-2.3 \%$ over the six days beginning the day before the announcement (significant at the $1 \%$ level for both tests). The latter result is consistent with the announcement of an SPP being bad news for shareholders, since the average drop-off due to the discount on the SPP shares is likely to be of the order of $0.5 \%$, as explained earlier. 
[Table 7]

Many SPPs (39\% of the sample) are issued with an associated placement. Further preliminary analysis was done on the share price reaction and associated factors contained in the SPP detail announcement (day -1 to 0) for SPPs that were and were not accompanied by a share placement. Consistent with prior literature, sample firms with an associated placement experience a less negative share price reaction although the difference is not significant at the $10 \%$ level. The relative offering size (anticipated) is larger when there is no associated placement, suggesting SPPs that accompany placements are smaller than stand alone SPPs. Those with an associated placement also experience a larger share price runup (10\% on average, compared to the $3.5 \%$ for stand alone SPPs). This suggests firms issuing placements are concerned about timing the issue, which is arguably more important for a larger issue such as a private placement. Generally, firms with SPPs and an associated placement are more likely to use the proceeds to reduce debt or strengthen the balance sheet. They are also significantly more likely to engage an underwriter, consistent with evidence that many private placements are underwritten (Hertzel and Smith 1993). Further, the price is determined and announced for SPPs with an associated placement for a significantly larger proportion of firms, consistent with findings that many SPPs are issued at the private placement price or a slight discount to it.

Figure 1 graphs the average cumulative return for both SPPs and the ASX All Ordinaries Accumulation Index over the 60 trading days leading up to the day before the SPP detail announcement. The $6.1 \%$ share price runup is substantially smaller than the 26\% reported by Gajewski and Ginglinger 2002 for French equity issues between 1986 and 1996.

[Figure 1]

A number of multivariate regression models were fitted by OLS to explain the within-sample variance of the share price reaction to the SPP detail announcement 
(measured over days -1 to +4 ) and to conduct robustness tests. The results are presented in Table 8. Model 1 includes all explanatory variables except relative offering size (restricted) and discount (stated). This model has an adjusted $R^{2}$ of $14 \%$, similar to the $14.7 \%$ reported by Gajewski and Ginglinger 2002, 7\% by Masulis and Korwar 1986 and $4.3 \%$ by Asquith and Mullins 1986, but much less than the $43 \%$ reported by Slovin, Sushka and Lai 2000. Five explanatory variables are significant at the $10 \%$ level or better. The prior runup, discount (calculated) and the eligibility dummy variable are significant at the $1 \%$ level; the negative coefficient for the discount suggests the market reacts more favourably to a smaller discount, consistent with Slovin, Sushka and Lai 2000. The relative offering size (anticipated) and the mining industry dummy variable are significant at the $5 \%$ level. However, both have the opposite sign to that predicted. The positive coefficient for share price runup suggests investors acknowledge firms are issuing SPPs when their stock is overvalued. The positive coefficient for the mining industry dummy variable means that announcing an SPP is interpreted by the market as a positive signal. The significant, negative coefficient on relative offering size (anticipated) supports the information asymmetry argument; specifically, announcing a larger offer is associated with a larger drop in share price. $^{15}$

[Table 8]

When we exclude financial firms (column 4), confine the sample to mining firms (column 5), and fit the model separately to plans with and without an associated share placement (columns 6 and 7), the principal results are robust. ${ }^{16}$ The direction of the coefficients on significant predictors - including offer size, runup, discount, industry and eligibility - are all consistent with the base model. The adjusted $R^{2}$ ranges from $9.10 \%$ to $22.80 \%$ and all models are significant.

\subsection{Long run performance after the issue}

\footnotetext{
${ }^{15}$ As a further sensitivity test, we re-ran the analysis partitioning the sample on the post-September 2002 regulatory changes. Partitioning the sample this way does not alter the tenor of results reported in Table 7.

${ }^{16}$ Since all plans with accompanying placements also announced the issue price, that variable is deleted from the model in column 7.
} 
Table 9 summarises long-run performance over one, two and three year horizons after the issue's announcement. The results are tabulated for two matched pair designs: (1) each issuer is matched with a non-SPP issuing firm based on size and industry; and (2) each issuer's performance is benchmarked against a comprehensive, equally weighted market index benchmark. ${ }^{17}$ The return is measured by the log of the buy-and-hold return for the indicated holding period. While there is no significant difference between the log return on the SPP issuer and its industry and size-matched counterpart in the first year after the SPP announcement month, in all other cases significant underperformance is found, with the significance level varying according to the benchmark and whether a $t$ test or ranks tests is applied. In sum, the results in Table 9 indicate SPP firms suffer significant long-run underperformance throughout the three years following the capital raising.

For robustness, we also implemented the CTAR procedure. In brief, ${ }^{18}$ when the monthly excess return on the portfolio comprising firms that had announced an SPP at any time during the previous 36 months was regressed by Weighted Least Squares (the weight was the number of stocks in the portfolio that month) on the market excess return and the returns on the size and book-to-market hedge portfolios, we estimated an average abnormal return of $-0.6 \%$ per month $(t=-2.41$, significant at $1 \%$ on a one-tailed test). When the structural equation was extended to include a momentum factor, it only added noise: the estimated abnormal return was still $-0.6 \%$ per month (extending for 36 months) but its significance level dropped to 0.05 . For both CTAR models, the adjusted $R^{2}$ was of the order of 0.89 .

\section{[Table 9]}

When a cross-sectional regression model of factors affecting the long-run performance of SPP issuers was fitted by Ordinary Least Squares, the dependent variable being the issuer's three year post-event return in excess of the market benchmark, we found the SPP-issuer did not perform as badly if it was in the mining industry, if it was

\footnotetext{
${ }^{17}$ The market index is EWMKT, which is compiled by the AGSM's Centre for Research in Finance.

${ }^{18}$ Details are available from the corresponding author.
} 
made by a company audited by a 'Big- $N$ ' audit firm, ${ }^{19}$ and if the issue was underwritten. Conversely, the greater the issue discount the worse the long run performance. The model adjusted $R^{2}$ was $14.6 \%(p<0.01, N=173){ }^{20}$

\section{Conclusion}

We have provided the first detailed empirical evidence on three important facets of SPPs in Australia.

First, we explored features of SPPs and the characteristics that distinguish SPPissuing firms from comparable firms in the same industry. The results showed SPPissuing firms are differentiated from their peers by lower levels of liquidity and cash holdings, and more disperse shareholdings.

Second, we examined the announcement effect of SPP issues and factors explaining the size of the market's reaction. Share prices, measured relative to the market, react negatively to the announcement of an SPP, with the size of the share price reaction being related to the size of the issue, the prior share price runup, the issue price discount, the firm's industry, and whether there is enough time for non-shareholders to buy shares in order to participate. The results were robust across industry, regulatory changes to SPP provisions and whether or not there is an associated share placement.

Third, we examined the long-run performance of SPP firms for periods up to three years after the announcement. Performance initially was measured by the issuing firm's buy-and-hold log return relative to that of a comparably-sized firm in the same industry, and to a broadly-based market index. Typically, we found long-run underperformance by the issuing firm over extended periods after the event. The CTAR procedure advocated by Fama 1998 confirmed this result. Cross-sectional regression analysis revealed some evidence that the SPP-issuer did not perform as badly if it was in the mining industry, if it was audited by a 'Big- $N$ ' firm, or if the issue was underwritten. Conversely, the greater the issue discount the worse the issuer's long run performance.

\footnotetext{
${ }^{19}$ Sixty per cent of the SPP issues were made by clients of Big- $N$ firms.

${ }^{20}$ The results are not tabulated to conserve space but are available from the corresponding author.
} 


\section{References}

Allen, D., Soucik, V., 1999a, "Long Run Underperformance of Seasoned Equity Offerings: Fact or Illusion?" Working Paper (Edith Cowan University).

Allen, D., Soucik, V., 1999b, "Performance of Seasoned Equity Offerings in a Risk Adjusted Environment," Working Paper (Edith Cowan University).

Ang, J., Zhang, S., 2004, "An Evaluation of Testing Procedures for Long Horizon Event Studies," Review of Quantitative Finance and Accounting, Vol. 23, pp. 251-274.

Antoniou, A., Guney, Y., Paudyal, K., 2002, "Determinants of Corporate Structure: Evidence from European Countries," Working Paper (University of Durham) (http://ssrn.com/abstract=302833).

Asquith, P., Mullins, D., 1986, "Equity Issues and Offering Dilution," Journal of Financial Economics, Vol. 15, pp. 61-89.

Australian Securities and Investment Commission (ASIC), 1997, "Policy Statement 125: Small Offers of Shares to Existing Shareholders by Listed Companies - Share Purchase Plans," Australian Investments and Securities Commission.

Australian Securities and Investment Commission (ASIC), 2002, "IR 02/17: ASIC Amends Policy on Share Purchase Plans," Australian Securities and Investments Commission.

Australian Securities and Investment Commission (ASIC), 2002, "Class Order 02/831," Australian Securities and Investments Commission.

Australian Stock Exchange (ASX), 1999, "ASX Media Release - ASX Settlement Moves to T+3," Australian Stock Exchange.

Australian Stock Exchange (ASX), 2004, "Fact File 2004 (Statistics to 31 December 2003)," (http://www.asx.com.au/about/pdf/ASX_Fact_File_2004.pdf).

Balatbat, M., Taylor, S., Walter, T., 2004, "Corporate Governance, Inside Ownership and Operating Performance of Australia Initial Public Offerings," Journal of Accounting and Finance, Vol. 44, pp. 299-328.

Barber, B., Lyon, J., 1997, "Detecting Long-Run Abnormal Stock Return: The Empirical Power and Specification of Test Statistics," Journal of Financial Economics, Vol. 43, pp. 341-372.

Bradley, M., Jarrell, G., Kim, E., 1984, "On the Existence of an Optimal Capital Structure: Theory and Evidence," Journal of Finance, Vol. 39, pp. 857-880.

Brav, A., Gompers, P., 1996, "Myth or Reality? The Long-Run Underperformance of Initial Public Offerings: Evidence from Venture and Non-Venture Capital-Based Companies, Working Paper (University of Chicago).

Brown, P., Ferguson, A., Stone, K., 2006, "Share Purchase Plans" JASSA Autumn, 1823.

Brown, P., Gallery, G., Goei, O., 2006, "Does Market Misvaluation Help Explain Share Market Long-Run Underperformance Following a Seasoned Equity Issue?" Accounting and Finance Vol. 46, 191-219.

Burton, B., Lonie, A., Power, D., 1999, "Does the Issue Method Influence the Market Reaction to Seasoned Equity Offer Announcements?" Applied Economic Letters, Vol. 6, pp. 459-462.

Burton, B., Power, D., 2003, "Evidence on the Determinants of Equity Issue Method in the UK," Applied Financial Economics, Vol. 13, pp. 145-157. 
Carter, R., Dark, F., Singh, A., 1998, "Underwriter Reputation, Initial Returns and the Long-Run Performance of IPO Stocks, ” Journal of Finance, Vol. 53, pp. 285-311.

Chemmanur, T., Fulghieri, P., 1994, "Investment Bank Reputation, Information Production and Financial Intermediation," Journal of Finance, Vol. 49, pp. 57-79.

Chiarella, C., Pham, T., Sim, A., Tan, M., 1991, "Determinants of Corporate Capital Structure: Australian Evidence," Working Paper (University of Technology Sydney).

Conrad, J., Kaul, G., 1993, "Long-Term Market Overreation or Biases in Computed Returns," Journal of Finance, Vol. 48, pp. 39-63.

Cragg, J., Baxter, N., 1970, “The Issuing of Corporate Securities," Journal of Political Economy, Vol. 79, pp. 1310-1324.

Datar, S., Feltham, G., Hughes, J., 1991, "The Role of Audits and Audit Quality in Valuing New Issues," Journal of Accounting and Economics, Vol. 14, pp. 3-49.

Dehnert, J., 1992, "A Study of SEOs in Australia," Working Paper (Doctoral Dissertation, UNSW).

Dehnert, J., 1993, "Private Placements in Australia," Working Paper (AGSM).

Donaldson, G., 1961, "Corporate Debt Capacity: A Study of Corporate Debt Policy and the Determination of Corporate Debt Capacity", Harvard University Graduate School of Business, Mass.

Eckbo, B., Masulis, R., 1992, “Adverse Selection and the Rights Offer Paradox," Journal of Financial Economics, Vol. 32, pp. 293-332.

Eckbo, B., Masulis, R., Norli, O., 2000, "Seasoned Public Offerings: Resolution of the "New Issues Puzzle," Journal of Financial Economics, Vol. 56, pp. 251-291.

Fama, E., 1998, "Market Efficiency, Long-Term Returns and Behavioral Finance," Journal of Financial Economics, Vol. 49, pp. 283-306.

Fama, E., French, K., 1992, "The Cross-Section of Expected Stock Returns," Journal of Finance, Vol. 47, pp. 427-465.

Fama, E., French, K., 1993, "Common Risk Factors in the Returns on Stocks and Bonds," Journal of Financial Economics, Vol. 33, pp. 3-56.

Ferguson, A., and A. Crockett., 2003, "Information Transfer and Press Coverage: The case of the Gawler Craton Gold boom," Pacific Basin Finance Journal, Vol. 11, pp. 101-120.

Gajewski, J., Ginglinger, E., 2002, "Seasoned Equity Issued in a Closely Held Market: Evidence from France," European Finance Review, Vol. 6, pp. 291-319.

Gaunt, C., Gray, P., McIvor, J., 2000, “The Impact of Share Price on Seasonality and Size Anomalies in Australian Equity Returns," Accounting and Finance, Vol. 40, pp. 33-50.

Gray, P., McAllister, J., 2002, "Assessing the Robustness of Market Overreaction to Alternate Measurement Methodologies," AFAANZ Conference, Australia.

Gray, P., Whittaker, M., 2003, "Future Long-Horizon Performance Measurement Conditional on Past Survival," International Review of Finance, Vol. 4, pp. 29-48.

Helou, A., Park, G., 2001, "Is There a Signaling Effect of Underwriter Reputation?" Journal of Financial Research, Vol. 24, pp. 27-43.

Hertzel, M., Lemmon, M., Linck, J., Rees, L., 2002, “Long-Run Performance Following Private Placement of Equity," Journal of Finance, Vol. 57, pp. 2595-2617.

Hertzel, M., Smith, R., 1993, "Market Discounts and Shareholder Gains for Placing Equity Privately," Journal of Finance, Vol. 48, pp. 459-485. 
Jensen, M., 1986, “Agency Costs of Free Cash Flow, Corporate Finance and the Market for Takeovers", American Economic Review, Vol. 79, pp. 323-329.

Lee, H., Kocher, C., 2001, "Firm Characteristics and Seasoned Equity Issuance Method: Private Placement Versus Public Offering," Journal of Applied Business Research, Vol. 17(3), pp. 23-36.

Leland, H., Pyle, D., 1977, "Information Asymmetries, Financial Structure and Financial Intermediaries," Journal of Finance, Vol. 32, pp. 371-388.

Loughran, T., Ritter, J., 2000, "The Uniformly Least Powerful Tests of Market Efficiency," Journal of Finance, Vol. 55, pp. 361-389.

Lyon, J., Barber, B., Tsai, C., 1999, "Improved Methods for Tests of Long-Run Abnormal Stock Returns," Journal of Finance, Vol. 54, pp. 165-201.

Marsh, P., 1982, “The Choice between Equity and Debt: An Empirical Study," Journal of Finance, Vol. 37, pp. 121-144.

Masulis, R., Korwar, A., 1986, "Seasoned Equity Offerings: An Empirical Investigation," Journal of Financial Economics, Vol. 15, pp. 91-118.

McCallum, J., 2002, "Share Purchase Plans a Hot Ticket," Business Review Weekly.

Michaely, R., Shaw, W., 1994, "The Pricing of Initial Public Offerings: Tests of Adverse Selection and Signaling Theories," Review of Financial Studies, Vol. 7, pp. 279-319.

Mikkelson, W., Partch, M., 1986, "Valuation Effects of Security Offerings and the Issuance Process," Journal of Financial Economics, Vol. 15, pp. 31-60.

Mitchell, M., Stafford, E., 2000, "Managerial Decision and Long-Run Stock Price Performance," Journal of Business, Vol. 73, pp. 287-320.

Myers, S., Majluf, N., 1984, "Corporate Financing and Investment Decisions When Firms Have Information That Investors Do Not Have," Journal of Financial Economics, Vol. 13, pp. 187-221.

Prosser Report, 2003, "Exploring: Australia's Future — impediments to increasing investment in minerals and petroleum exploration in Australia," House of Representatives Standing Committee on Industry and Resources.

Rajan, R., Zingales, L., 1995, "What Do We Know About Capital Structure? Some Evidence from International Data," Journal of Finance, Vol. 50, pp. 1421-1460.

Ritter, J., 1991, “The Long-Run Performance of Initial Public Offerings," Journal of Finance, Vol. 46, pp. 3-27.

Slovin, M., Sushka, M., Lai, K., 2000, “Alternative Flotation Methods, Adverse Selection and Ownership Structure: Evidence from Seasoned Equity Issuance in the UK," Journal of Financial Economics, Vol. 57, pp. 157-190.

Spiess, K., Affleck-Graves, J., 1995, "Underperformance in Long-Run Stock Returns Following Seasoned Equity Offerings," Journal of Financial Economics, Vol. 38, pp. 243-267.

Taub, A., 1975, "Determinants of the Firm's Capital Structure," Review of Economics and Statistics, Vol. 57, pp. 410-416.

The Intelligent Investor, 2005, "The Ins and Outs of Share Purchase Plans," Sharemarket Basics (http://www.etradeaustralia.com.au).

Titman, S., Wessels, R., 1988, “The Determinants of Capital Structure Choice,” Journal of Finance, Vol. 43, pp. 1-19. 
Weber, J., Willenborg, M., 2003, "Do Expert Informational Intermediaries Add Value? Evidence from Auditors in Microcap IPOs," Journal of Accounting Research, Vol. 41, pp. 681-720.

Wruck, K., 1989, "Equity Ownership Concentration and Firm Value: Evidence from Private Equity Financing," Journal of Financial Economics, Vol. 23, pp. 3-28. 
Table 1

Number of SPP detail announcements, by industry and year

\begin{tabular}{|c|c|c|c|c|c|c|c|c|c|c|c|c|c|c|c|c|c|c|c|}
\hline \multirow[b]{2}{*}{ Industry } & \multicolumn{15}{|c|}{ Calendar year of the SPP detail announcement } & \multirow{2}{*}{$\begin{array}{c}\text { Total } \\
\text { no. of } \\
\text { issues }\end{array}$} & \multirow{2}{*}{$\begin{array}{l}\% \text { of } \\
\text { total }\end{array}$} & \multirow{2}{*}{$\begin{array}{c}\text { Total } \\
\text { no. of } \\
\text { issuers } \\
\end{array}$} & \multirow{2}{*}{$\begin{array}{l}\% \text { of } \\
\text { total }\end{array}$} \\
\hline & 91 & 92 & 93 & 94 & 95 & 96 & 97 & 98 & 99 & 00 & 01 & 02 & 03 & 04 & 05 & & & & \\
\hline Materials & 1 & 3 & 1 & 2 & 2 & 1 & 4 & 1 & 1 & 1 & 6 & 41 & 52 & 51 & 20 & 187 & $32 \%$ & 128 & $33 \%$ \\
\hline Financials & & & & & & 4 & 4 & 6 & 7 & 8 & 12 & 18 & 20 & 17 & 5 & 101 & $17 \%$ & 46 & $12 \%$ \\
\hline Health Care & & & & 1 & & & & & 2 & 2 & 3 & 15 & 24 & 20 & 3 & 70 & $12 \%$ & 48 & $12 \%$ \\
\hline Energy & & & & & & & & & 1 & 1 & 2 & 16 & 8 & 11 & 11 & 50 & $8 \%$ & 39 & $10 \%$ \\
\hline Industrials & & & & & & & 1 & & & & 5 & 8 & 13 & 12 & 8 & 47 & $8 \%$ & 41 & $10 \%$ \\
\hline $\begin{array}{l}\text { Information } \\
\text { Technology }\end{array}$ & & & & & & & 1 & & 1 & & 2 & 8 & 7 & 10 & 5 & 34 & $6 \%$ & 20 & $5 \%$ \\
\hline Delisted & & 1 & 1 & & & 2 & 2 & 4 & 3 & 4 & 5 & 2 & 1 & 5 & & 30 & $5 \%$ & 17 & $4 \%$ \\
\hline $\begin{array}{l}\text { Consumer } \\
\text { Discretionary }\end{array}$ & & & & & & & & & & & & 7 & 11 & 9 & & 27 & $5 \%$ & 24 & $6 \%$ \\
\hline Consumer Staples & & & & & & & & & 1 & & 1 & 5 & 4 & 7 & 1 & 19 & $3 \%$ & 16 & $4 \%$ \\
\hline Utilities & & & & & & & & 1 & 1 & 1 & 2 & 3 & 4 & 3 & 1 & 16 & $3 \%$ & 6 & $2 \%$ \\
\hline $\begin{array}{l}\text { Telecommunication } \\
\text { Services }\end{array}$ & & & & & & & & & & & & 2 & 6 & 1 & 1 & 10 & $2 \%$ & 8 & $2 \%$ \\
\hline Total & 1 & 4 & 2 & 3 & 2 & 7 & 12 & 12 & 17 & 17 & 38 & 125 & 150 & 146 & 55 & 591 & $100 \%$ & 393 & $100 \%$ \\
\hline$\%$ of total & $0 \%$ & $1 \%$ & $0 \%$ & $1 \%$ & $0 \%$ & $1 \%$ & $2 \%$ & $2 \%$ & $3 \%$ & $3 \%$ & $6 \%$ & $21 \%$ & $25 \%$ & $25 \%$ & $9 \%$ & $100 \%$ & & & \\
\hline
\end{tabular}


Table 2

Descriptive statistics

\begin{tabular}{|c|c|c|c|c|c|c|}
\hline Variable & $\mathrm{N}$ & Mean & Median & St. dev. & Min. & Max. \\
\hline \multicolumn{7}{|c|}{ Panel A: Characteristics of SPPs issued from 1991 to 2005} \\
\hline Discount (\%) & 559 & 11.12 & 9.74 & 10.90 & -26.90 & 48.53 \\
\hline Issue size $(\$ 000)$ & 575 & 10,400 & 1454 & 39,600 & 8 & 500,000 \\
\hline Issue size / Mkt Cap (\%) & 473 & 7.2 & 4.1 & 9.2 & 0.01 & 63 \\
\hline Time to issue (days) & 551 & 51 & 44 & 29 & 14 & 415 \\
\hline Uptake rate $(\%)$ & 373 & 66 & 57 & 52 & 1 & 277 \\
\hline \multicolumn{7}{|c|}{ Panel B: Share return (-1 to 0) and other variables } \\
\hline Return & 537 & -0.004 & -0.002 & 0.065 & -0.166 & 0.203 \\
\hline Offering size (Ant) & 313 & 0.148 & 0.129 & 0.112 & 0.012 & 0.507 \\
\hline Offering size (Res) & 536 & 15.673 & 15.317 & 2.012 & 12.413 & 20.499 \\
\hline Firm size & 535 & 17.265 & 16.718 & 2.300 & 13.487 & 23.019 \\
\hline Runup & 525 & 0.061 & 0.033 & 0.318 & -0.598 & 1.065 \\
\hline Discount (Cal) & 383 & 0.116 & 0.103 & 0.091 & -0.087 & 0.333 \\
\hline Discount (Stated) & 448 & 0.121 & 0.101 & 0.070 & 0.025 & 0.310 \\
\hline Industry & 537 & 0.42 & & & & \\
\hline Use & 537 & 0.10 & & & & \\
\hline Director & 537 & 0.13 & & & & \\
\hline Underwriter & 537 & 0.12 & & & & \\
\hline Price & 537 & 0.71 & & & & \\
\hline Placement & 537 & 0.39 & & & & \\
\hline Eligibility & 537 & 0.43 & & & & \\
\hline
\end{tabular}

Discount

Issue size (\$000)

Issue size relative to market cap (\%)

Time to issue (days)

Uptake rate (\%)

Return

Offering size (Ant)

Offering size (Res)

Firm size

Runup

Discount (Cal)

Discount (Stated)

Industry

Use
$=1$ minus SPP offer price divided by the average closing market price prevailing on the five days before the SPP detail announcement, expressed as a \%.

$=$ total dollar amount of capital raised

= total dollar amount of capital raised scaled by market capitalisation at the month end prior to the SPP detail announcement

$=$ difference between the date SPP shares are allotted and the date of the SPP detail announcement (or first announcement of the SPP) (in days)

$=\%$ of the amount raised to the anticipated amount to be raised

$=$ mean excess return over the announcement period (day -1 to 0 )

$=$ anticipated number of shares issued divided by the number of shares outstanding prior to the issue plus the anticipated number of shares

$=$ natural logarithm of $15 \%$ of market capitalization on the announcement day

$=$ natural logarithm of total assets

$=$ share return over last 60 trading days before SPP detail announcement

$=1$ minus the SPP offer price divided by the average closing price prevailing on the 5 days prior the SPP detail announcement

$=$ percentage discount stated in the SPP detail announcement

$=1$ if the firm is classified as a mining firm, 0 otherwise

$=1$ if the intended use of proceeds is to reduce debts and/or strengthen the balance sheet, 0 otherwise 
Director

Underwriter

Price

Placement

Eligibility
$=1$ if directors wereto participate in the SPP detail announcement, 0 otherwise $=1$ if SPP is underwritten SPP, 0 otherwise

$=1$ if the SPP price is indicated in the SPP detail announcement, 0 otherwise

$=1$ if an associated placement is indicated, 0 otherwise

$=1$ if the record date is more than 5 days after the SPP detail announcement, 0 otherwise. 
Table 3

Characteristics of firms that issue SPPs: descriptive statistics

\begin{tabular}{llcccccccc}
\hline Variable & & $\mathrm{N}$ & Mean & Median & dev. & Min. & Max. & Skew. & Kurt. \\
\hline Age & & 588 & 14.52 & 10.05 & 15.18 & 0.00 & 131.52 & 2.83 & 15.87 \\
Size & MC & 501 & 22.36 & 21.86 & 2.45 & 18.79 & 28.71 & 0.81 & 2.89 \\
& TA & 588 & 17.66 & 16.84 & 2.79 & 13.49 & 26.25 & 1.07 & 3.74 \\
Growth \& & BVE/ & 501 & 0.13 & 0.01 & 0.49 & 0.00 & 3.00 & 5.01 & 28.17 \\
investment & MVE & & & & & & & & \\
& CapEx/ & 588 & 0.09 & 0.04 & 0.13 & 0.00 & 0.58 & 1.99 & 6.64 \\
& TA & & & & & & & & \\
Liquidity & CA/CL & 587 & 4.83 & 1.77 & 8.02 & 0.11 & 42.89 & 3.18 & 13.51 \\
Profit & FCF/TA & 588 & 0.05 & 0.09 & 0.36 & -1.23 & 0.76 & -1.21 & 5.68 \\
& EBITDA & 588 & -0.15 & -0.04 & 0.35 & -1.55 & 0.25 & -2.16 & 8.29 \\
Cash & /TA & & & & & & & & \\
holdings & Net cash & 588 & -0.12 & -0.04 & 0.29 & -1.35 & 0.24 & -2.29 & 9.12 \\
& Cash & 567 & -0.05 & 0.00 & 0.24 & -1.03 & 0.56 & -1.49 & 8.68 \\
Leverage & burn & & & & & & & & \\
& TD/TA & 587 & 0.16 & 0.04 & 0.23 & 0.00 & 0.91 & 1.71 & 5.34 \\
TD/(TD & 556 & 0.11 & 0.00 & 0.30 & 0.00 & 1.00 & 2.66 & 8.14 \\
Sividend behaviour & 588 & 0.36 & & & & & & &
\end{tabular}

\begin{tabular}{|c|c|}
\hline Age & $\begin{array}{l}=\text { difference in years between the ASX listing date and the SPP detail } \\
\text { announcement }\end{array}$ \\
\hline Size (MC) & $\begin{array}{l}=\text { natural logarithm of market capitalisation (SPPR) for balance date prior to the } \\
\text { SPP detail announcement }\end{array}$ \\
\hline Size (TA) & $\begin{array}{l}=\text { natural logarithm of total assets (Aspect }-\# 5090) \text { for balance date prior to the } \\
\text { SPP detail announcement }\end{array}$ \\
\hline $\begin{array}{l}\text { Growth \& investment } \\
\text { (BE/MVE) }\end{array}$ & $\begin{aligned}= & \text { book value of equity (total shareholders equity (Aspect - \#7010) less } \\
& \text { convertible equity (Aspect - \#7015)) scaled by market value equity (market } \\
& \text { capitalisation) for balance date prior to the SPP detail announcement }\end{aligned}$ \\
\hline $\begin{array}{l}\text { Growth \& investment } \\
\text { (CapEx/TA) }\end{array}$ & $\begin{aligned}= & \text { absolute value of capital expenditure (Aspect }-\# 9150) \text { scaled by total assets } \\
& (\text { Aspect }-\# 5090) \text { for balance date prior to the SPP detail announcement }\end{aligned}$ \\
\hline Liquidity (CA/CL) & $\begin{aligned}= & \text { current assets (Aspect }-\# 5020 \text { ) divided by current liabilities (Aspect }-\# 6010 \text { ) } \\
& \text { for balance date prior to the SPP detail announcement }\end{aligned}$ \\
\hline $\begin{array}{l}\text { Profitability } \\
\text { (FCF/TA) }\end{array}$ & $\begin{array}{l}=\text { net cash from operations (Aspect - \#9100) less net cash from investing } \\
\text { activities (Aspect - \#9200) less total dividend on ordinary and preferred } \\
\text { dividends paid out (Aspect - \#9217) less repayment of borrowings (Aspect - } \\
\text { \#9215) scaled by total assets (Aspect - \#5090) for balance date prior to the SPP } \\
\text { detail announcement }\end{array}$ \\
\hline $\begin{array}{l}\text { Profitability } \\
\text { (EBITDA/TA) }\end{array}$ & $\begin{aligned} &= \text { earnings before interest and tax (Aspect - \#8012) less depreciation and } \\
& \text { amortisation (Aspect - \#8010) scaled by total assets (Aspect - \#5090) for } \\
& \text { balance date prior to the SPP detail announcement }\end{aligned}$ \\
\hline ash holdings & $=$ receipts from customers (Aspect $-\# 800)$ less payments to suppliers and \\
\hline
\end{tabular}


(Net cash)

Cash holdings

(Cash burn)

Leverage (TD/TA)

Leverage

(TD/(TD+MVE))

Dividend behaviour

Shareholder structure

Overseas exchange employees (Aspect - \#801) scaled by total assets (Aspect - \#5090) for balance date prior to the SPP detail announcement

$=$ cash in the current period less cash in the prior period (Aspect - \#4990) scaled by total assets (Aspect - \#5090) where current period is the balance date prior to the SPP detail announcement

= book value of total debt (Aspect - \#6000 and \#6020) scaled by total assets (Aspect - \#5090) for balance date prior to the SPP detail announcement

= book value of total debt (Aspect $-\# 6000$ and \#6020) divided by the book value of total debt (Aspect - \#6000 and \#6020) plus the market value of equity (market capitalisation) for balance date prior to the SPP detail announcement

$=1$ if a dividend was paid for the balance date prior to the SPP detail announcement and 0 otherwise

$=$ percentage held by non-top 20 shareholders $((100-$ Aspect $-\# 709) / 100)$ for the balance date prior to the SPP detail announcement

$=1$ if the firm is listed only on the Australian and/or New Zealand Stock Exchange and 0 otherwise 
Table 4

Sample size

\begin{tabular}{cc}
\hline Selection criteria & $N$ \\
\hline Panel A: Reconciliation of SPPs subject to the financing decision analysis
\end{tabular}

Number of SPPs available during the period 1991-2005 591

less SPPs with no GICS code available

less SPPs with no market capitalisation match

less SPPs with a match beyond the $+/-30 \%$ threshold

less SPPs with unavailable data for one or more explanatory variable

Number of SPPs subject to the financing decision analysis

Panel B: Reconciliation of SPPs subject to the announcement effect analysis

Number of SPPs available during the period 1991-2005

less SPPs with no SPP detail announcement

less SPPs with insufficient share price data to measure returns

less SPPs with no data for one or more explanatory variable

Number of SPPs subject to the share price reaction analysis 
Table 5

Comparison of the characteristics of SPP-issuing firms and their matched counterparts

\begin{tabular}{|c|c|c|c|c|c|c|c|c|}
\hline \multirow{2}{*}{\multicolumn{2}{|c|}{ Firm characteristic }} & \multirow[t]{2}{*}{$N$} & \multicolumn{2}{|c|}{ SPP-issuing firms } & \multicolumn{2}{|c|}{$\begin{array}{c}\text { Matched non- } \\
\text { SPP-issuing firms }\end{array}$} & \multicolumn{2}{|c|}{ Difference tests } \\
\hline & & & Mean & Median & Mean & Median & $t$-test & Wilcoxon \\
\hline \multirow[t]{2}{*}{ Size } & $\mathrm{MC}$ & 429 & 22.06 & 21.58 & 22.06 & 21.57 & 0.29 & -0.47 \\
\hline & TA & 429 & 17.47 & 16.78 & 17.55 & 16.98 & -1.29 & -0.91 \\
\hline \multirow{2}{*}{$\begin{array}{l}\text { Growth \& } \\
\text { investment }\end{array}$} & BVE/MVE & 429 & 0.10 & 0.01 & 0.07 & 0.01 & 1.35 & 1.30 \\
\hline & CapEx/TA & 429 & 0.10 & 0.04 & 0.09 & 0.04 & 1.47 & $2.21 * *$ \\
\hline Liquidity & CA/CL & 429 & 5.45 & 1.89 & 7.85 & 1.72 & $-2.99 * * *$ & -1.11 \\
\hline \multirow[t]{2}{*}{ Profit } & $\mathrm{FCF} / \mathrm{TA}$ & 429 & 0.06 & 0.09 & 0.11 & 0.12 & $-2.49 * *$ & $-2.12 * *$ \\
\hline & $\begin{array}{l}\text { EBITDA } \\
\text { /TA }\end{array}$ & 429 & -0.15 & -0.05 & -0.08 & 0.00 & $-3.59 * * *$ & $-4.24 * * *$ \\
\hline \multirow{2}{*}{$\begin{array}{l}\text { Cash } \\
\text { holdings }\end{array}$} & Net cash & 429 & -0.11 & -0.05 & -0.03 & -0.01 & $-5.78 * * *$ & $-5.29 * * *$ \\
\hline & Cash burn & 386 & -0.04 & 0.00 & 0.00 & 0.00 & $-2.87 * * *$ & $-2.17 * *$ \\
\hline \multirow[t]{2}{*}{ Leverage } & TD/TA & 428 & 0.15 & 0.03 & 0.15 & 0.04 & -0.19 & 0.30 \\
\hline & $\begin{array}{l}\text { TD/(TD } \\
+\mathrm{MVE})\end{array}$ & 429 & 0.00 & 0.00 & 0.01 & 0.00 & -0.84 & -0.03 \\
\hline \multicolumn{2}{|c|}{ Dividend behaviour } & 429 & 0.34 & & 0.40 & & $-2.74 * * *$ & $-2.72 * * *$ \\
\hline \multicolumn{2}{|c|}{ Shareholder structure } & 403 & 0.49 & 0.50 & 0.37 & 0.37 & $9.55 * * *$ & $8.49 * * *$ \\
\hline \multicolumn{2}{|c|}{ Overseas exchange } & 429 & 0.86 & & 0.87 & & -0.65 & -0.66 \\
\hline
\end{tabular}

$*, * *, * * *$ indicates significance at the $10 \%, 5 \%$ and $1 \%$ level on a two-tailed test.

Size (MC)

Size (TA)

Growth \& investment (BE/MVE)

Growth \& investment

(CapEx/TA)

Liquidity (CA/CL)

Profitability

(FCF/TA)

Profitability

(EBITDA/TA)

Cash holdings

(Net cash)

Cash holdings
= natural logarithm of market capitalisation (AGSM SPPR database) for balance date prior to the SPP detail announcement

$=$ natural logarithm of total assets (Aspect - \#5090) for balance date prior to the SPP detail announcement

= book value of equity (total shareholders equity (Aspect $-\# 7010$ ) less convertible equity (Aspect - \#7015)) scaled by market value of equity (market capitalisation) for balance date prior to the SPP detail announcement

$=$ absolute value of capital expenditure (Aspect - \#9150) scaled by total assets (Aspect - \#5090) for balance date prior to the SPP detail announcement

= current assets (Aspect $-\# 5020)$ divided by current liabilities (Aspect $-\# 6010$ ) for balance date prior to the SPP detail announcement

$=$ net cash from operations (Aspect $-\# 9100)$ less net cash from investing activities (Aspect - \#9200) less total dividend on ordinary and preferred dividends paid out (Aspect - \#9217) and less repayment of borrowings (Aspect - \#9215) scaled by total assets (Aspect - \#5090) for balance date prior to the SPP detail announcement

$=$ earnings before interest and tax (Aspect - \#8012) less depreciation and amortisation (Aspect - \#8010) scaled by total assets (Aspect - \#5090) for balance date prior to the SPP detail announcement

$=$ receipts from customers (Aspect $-\# 800)$ less payments to suppliers and employees (Aspect - \#801) scaled by total assets (Aspect - \#5090) for balance date prior to the SPP detail announcement

$=$ cash in the current period less cash in the prior period (Aspect $-\# 4990)$ scaled 
(Cash burn) by total assets (Aspect - \#5090) where current period is the balance date prior to the SPP detail announcement

Leverage $(\mathrm{TD} / \mathrm{TA}) \quad=$ book value of total debt (Aspect $-\# 6000$ and \#6020) scaled by total assets (Aspect - \#5090) for balance date prior to the SPP detail announcement

Leverage

(TD/(TD+MVE))

= book value of total debt (Aspect - \#6000 and \#6020) divided by the book value of total debt (Aspect - \#6000 and \#6020) plus the market value of equity (market capitalisation) for balance date prior to the SPP detail announcement

Dividend behaviour

$=1$ if a dividend was paid for the balance date prior to the SPP detail announcement and 0 otherwise

Shareholder structure

$=$ percentage held by non-top 20 shareholders $((100-$ Aspect $-\# 709) / 100)$ for the balance date prior to the SPP detail announcement

Overseas exchange $\quad=1$ if the firm is listed only on the Australian and/or New Zealand Stock Exchange and 0 otherwise 
Table 6

Logistic regression results: base case and various sub-samples

\begin{tabular}{|c|c|c|c|c|c|c|c|}
\hline \multicolumn{2}{|c|}{ Firm characteristic } & $\begin{array}{c}\text { Predicted } \\
\text { Sign }\end{array}$ & $\begin{array}{l}\text { Base } \\
\text { Model }\end{array}$ & $\begin{array}{c}\text { Excl. } \\
\text { finance }\end{array}$ & $\begin{array}{c}\text { Mining } \\
\text { firms }\end{array}$ & $\begin{array}{c}\text { Place- } \\
\text { ment }\end{array}$ & $\begin{array}{c}\text { No } \\
\text { Place- } \\
\text { ment }\end{array}$ \\
\hline \multirow{2}{*}{\multicolumn{2}{|c|}{ Intercept }} & & -1.377 & -1.053 & -1.217 & -0.64 & -1.834 \\
\hline & & & $-4.42 * * *$ & $-3.09^{* * *}$ & $-2.60^{* * *}$ & -1.29 & $-4.40^{* * *}$ \\
\hline \multirow{2}{*}{$\begin{array}{l}\text { Growth \& } \\
\text { investment }\end{array}$} & CapEx/TA & $?$ & 0.592 & 0.674 & 0.925 & 0.38 & 0.535 \\
\hline & & & 0.89 & 0.98 & 1.03 & 0.41 & 0.56 \\
\hline \multirow[t]{2}{*}{ Liquidity } & $\mathrm{CA} / \mathrm{CL}$ & - & -0.024 & -0.037 & -0.039 & -0.06 & -0.013 \\
\hline & & & $-3.43 * * *$ & $-4.30^{* * *}$ & $-3.48^{* * *}$ & $-3.38^{* * *}$ & -1.63 \\
\hline \multirow[t]{2}{*}{ Profitability } & EBITDA/TA & $?$ & 0.462 & 0.671 & 0.783 & 0.32 & 0.570 \\
\hline & & & 1.13 & 1.61 & 1.40 & 0.53 & 1.02 \\
\hline \multirow{4}{*}{$\begin{array}{l}\text { Cash } \\
\text { holdings } \\
\text { Leverage }\end{array}$} & Net cash & $?$ & -2.020 & -2.013 & -2.181 & -2.19 & -2.076 \\
\hline & & & $-3.47 * * *$ & $-3.38^{* \star \star}$ & $-2.38^{* *}$ & $-2.45^{\star *}$ & $-2.59^{* * *}$ \\
\hline & $\mathrm{TD} /$ & $?$ & -7.758 & 1.736 & 0.801 & 0.01 & -10.809 \\
\hline & (TD+MVE) & & -1.25 & 0.16 & 0.04 & 0.00 & -1.56 \\
\hline \multirow{2}{*}{\multicolumn{2}{|c|}{ Dividend behaviour }} & - & 0.184 & -0.062 & -0.062 & -0.161 & 0.303 \\
\hline & & & 0.94 & -0.28 & -0.28 & -0.45 & 1.16 \\
\hline \multirow{2}{*}{\multicolumn{2}{|c|}{ Shareholder structure }} & + & 3.180 & 3.108 & 3.108 & 3.577 & 3.785 \\
\hline & & & $7.88 * * *$ & $6.64^{* * *}$ & $6.64^{* * *}$ & $5.33^{* * *}$ & $6.98^{* * *}$ \\
\hline \multirow{2}{*}{\multicolumn{2}{|c|}{ Overseas exchange }} & + & 0.005 & -0.211 & -0.211 & -0.271 & 0.047 \\
\hline & & & 0.02 & -0.92 & -0.92 & -0.95 & 0.18 \\
\hline \multicolumn{2}{|l|}{$N$} & & 806 & 668 & 344 & 320 & 486 \\
\hline \multicolumn{2}{|l|}{ Chi-square } & & $89.17 * * *$ & $74.37 * * *$ & $44.23 * * *$ & $33.07 * * *$ & $60.71 * * *$ \\
\hline \multicolumn{2}{|l|}{ Pseudo $R^{2}$} & & $9.50 \%$ & $10.15 \%$ & $12.08 \%$ & $9.95 \%$ & $11.41 \%$ \\
\hline \multicolumn{2}{|c|}{ Classificatory accuracy } & & $65.26 \%$ & $66.17 \%$ & $66.86 \%$ & $63.13 \%$ & $67.49 \%$ \\
\hline
\end{tabular}




\section{Table 7}

Share return for three event windows defined relative to the SPP detail announcement date (day 0): test statistics for a non-zero effect

\begin{tabular}{lccc}
\hline & \multicolumn{3}{c}{ Period relative to the announcement (day 0) } \\
Statistic & $(-5,-2)$ & $(-1,0)$ & $(-1,4)$ \\
\hline Mean excess return & 0.007 & -0.004 & -0.023 \\
t-test & $1.98^{* *}$ & -1.29 & $-5.93 * * *$ \\
Wilcoxon signed rank test & 0.28 & $-2.08^{* *}$ & $-6.48^{* * *}$ \\
$\%$ Negative & $51 \%$ & $54 \%$ & $62 \%$ \\
$N$ & 536 & 537 & 537 \\
\hline
\end{tabular}

$*, * *, * * *$ indicates significance at the $10 \%, 5 \%$ and $1 \%$ level on a two-tailed test. 
Table 8

Cross-sectional regression models of factors affecting the share price reaction to the SPP detail announcement (days -1 to +4 ), fitted by OLS: base case and various sub-samples

\begin{tabular}{|c|c|c|c|c|c|c|}
\hline Factor & $\begin{array}{l}\text { Predicted } \\
\text { Sign }\end{array}$ & $\begin{array}{l}\text { Base } \\
\text { Model }\end{array}$ & $\begin{array}{c}\text { Excl. } \\
\text { financials }\end{array}$ & $\begin{array}{l}\text { Mining } \\
\text { firms }\end{array}$ & $\begin{array}{c}\text { Place- } \\
\text { ment }\end{array}$ & $\begin{array}{c}\text { No Place- } \\
\text { ment }\end{array}$ \\
\hline \multirow[t]{2}{*}{ Intercept } & & 0.094 & 0.107 & 0.150 & 0.135 & -0.035 \\
\hline & & 0.78 & 0.87 & 1.02 & 0.97 & -0.33 \\
\hline \multirow[t]{2}{*}{ Offering size (Ant) } & - & -0.123 & -0.120 & -0.239 & -0.081 & -0.187 \\
\hline & & $-2.07 * *$ & $-1.93 *$ & $-2.74 * * *$ & -0.99 & $-2.08 * *$ \\
\hline \multirow[t]{2}{*}{ Firm size } & - & -0.000 & -0.001 & -0.007 & -0.003 & 0.004 \\
\hline & & -0.03 & -0.14 & -1.12 & -0.57 & 0.73 \\
\hline \multirow[t]{2}{*}{ Runup } & - & 0.051 & 0.042 & 0.040 & 0.086 & 0.022 \\
\hline & & $2.85 * * *$ & $2.29 * *$ & $1.74 *$ & $3.18 * * *$ & 0.86 \\
\hline \multirow[t]{2}{*}{ Discount (Cal) } & $?$ & -0.301 & -0.348 & -0.446 & -0.317 & -0.290 \\
\hline & & $-4.53 * * *$ & $-5.07 * * *$ & $-4.67 * * *$ & $-3.45 * * *$ & $-2.86 * * *$ \\
\hline \multirow[t]{2}{*}{ Industry } & + & -0.030 & -0.030 & & -0.028 & -0.037 \\
\hline & & $-2.50 * *$ & $-2.36 * *$ & & $-1.68 *$ & $-1.95 *$ \\
\hline \multirow[t]{2}{*}{ Use } & - & -0.017 & -0.023 & 0.031 & -0.010 & -0.028 \\
\hline & & -0.97 & -1.27 & 0.95 & -0.44 & -0.85 \\
\hline \multirow[t]{2}{*}{ Director } & + & -0.022 & -0.021 & -0.016 & -0.024 & -0.021 \\
\hline & & -1.40 & -1.32 & -0.83 & -0.98 & -0.99 \\
\hline \multirow[t]{2}{*}{ Underwriter } & + & 0.010 & 0.005 & 0.029 & 0.003 & 0.027 \\
\hline & & 0.69 & 0.28 & 1.30 & 0.16 & 1.14 \\
\hline \multirow[t]{2}{*}{ Price } & + & -0.069 & -0.070 & -0.029 & -0.062 & \\
\hline & & -0.73 & -0.74 & -0.29 & -0.66 & \\
\hline \multirow[t]{2}{*}{ Placement } & + & 0.007 & 0.011 & 0.019 & & \\
\hline & & 0.58 & 0.87 & 1.03 & & \\
\hline \multirow[t]{2}{*}{ Eligibility } & + & 0.033 & 0.032 & 0.040 & 0.025 & 0.036 \\
\hline & & $2.76 * * *$ & $2.62 * * *$ & $2.43 * *$ & 1.49 & $2.00 * *$ \\
\hline$N$ & & 261 & 242 & 130 & 138 & 123 \\
\hline$F$-value & & $4.863^{* * *}$ & $4.779 * * *$ & $4.806^{* * *}$ & $2.371 * * *$ & $3.503 * * *$ \\
\hline Adjusted $R^{2}$ & & $14.00 \%$ & $14.70 \%$ & $22.80 \%$ & $9.10 \%$ & $15.60 \%$ \\
\hline
\end{tabular}

$*, * *, * * *$ indicates significance at the $10 \%, 5 \%$ and $1 \%$ level on a two-tailed test. 


\section{Table 9}

Long run share market performance of firms that adopted SPPs relative to two benchmarks: Firms in the same industry and of comparable size, and the market as a whole.

\begin{tabular}{|c|c|c|c|c|c|c|}
\hline \multirow{2}{*}{$\begin{array}{l}\text { Holding } \\
\text { Period }\end{array}$} & \multicolumn{3}{|c|}{ Matched non-SPP issuer } & \multicolumn{3}{|c|}{ Market Index } \\
\hline & $N$ & Mean & Median & $N$ & Mean & Median \\
\hline \multirow[t]{2}{*}{1 year } & 177 & $-3.52 \%$ & $1.17 \%$ & 384 & $-18.66 \%$ & $-15.79 \%$ \\
\hline & & -0.68 & 0.58 & & $-6.90 * * *$ & $-6.76 * * *$ \\
\hline \multirow[t]{2}{*}{2 years } & 165 & $-14.90 \%$ & $-13.33 \%$ & 326 & $-38.05 \%$ & $-31.74 \%$ \\
\hline & & $-1.88 *$ & $-2.04 * *$ & & $-8.54 * * *$ & $-7.99 * * *$ \\
\hline \multirow[t]{2}{*}{3 years } & 104 & $-22.12 \%$ & $-10.71 \%$ & 234 & $-62.66 \%$ & $-48.16 \%$ \\
\hline & & $-1.86 *$ & $-1.82 *$ & & $-9.29 * * *$ & $-8.22 * * *$ \\
\hline
\end{tabular}


Figure 1

Runup: Average cumulative return over the last 60 trading days before the SPP detail announcement

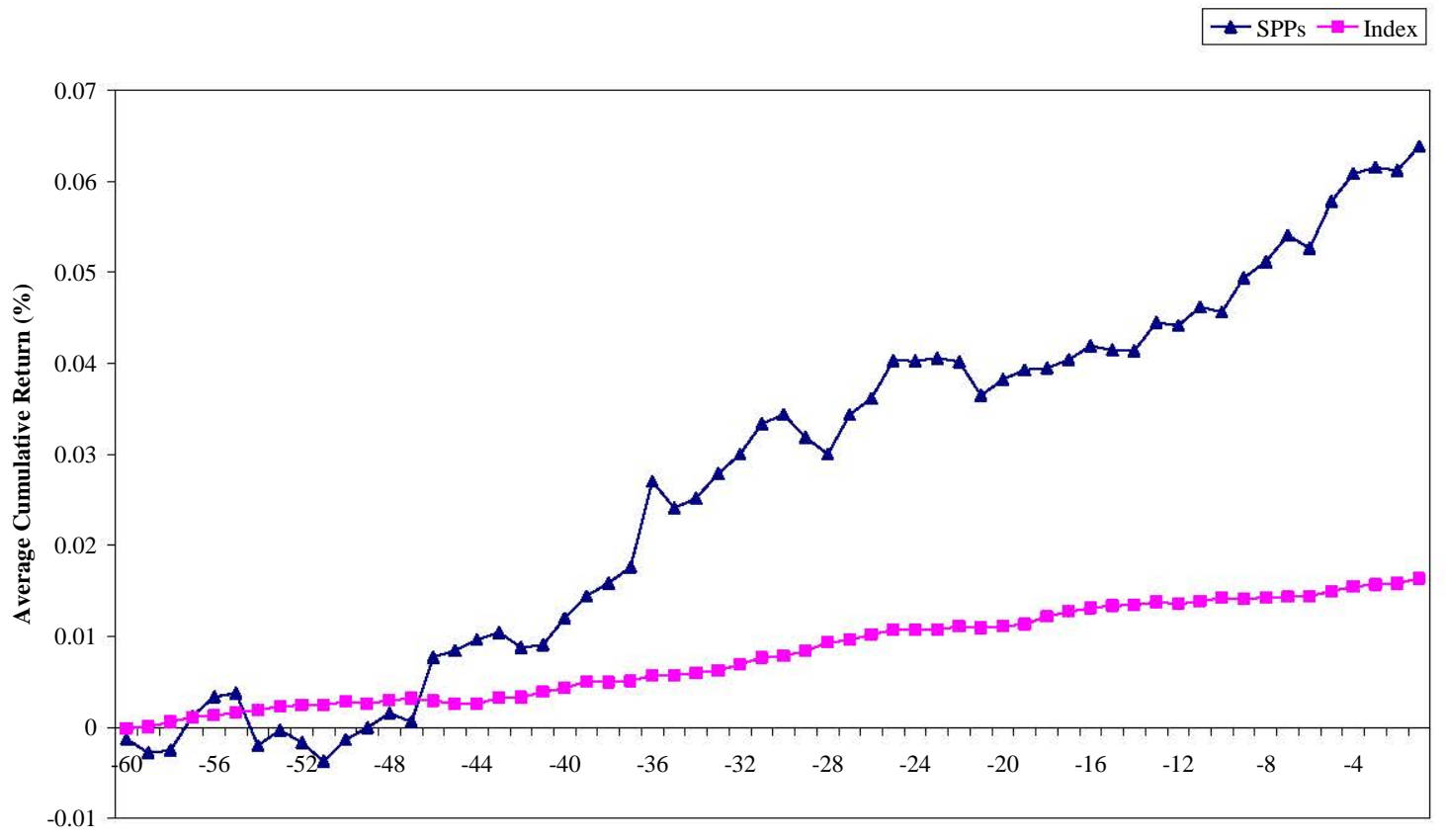

Day (Relative to Announcement) 